\title{
MANIPULATION OF INCEPTISOLS POND BOTTOM SOIL THROUGH ADDITION OF ULTISOLS AND VERTISOLS FOR REARING OF RED TILAPIA (Oreochromis sp.) LARVAE
}

\author{
Saberina Hasibuan"\#\#, Bambang Djadmo Kertonegoro*), Kamiso Handoyo Nitimulyo ${ }^{* * *(*)}$, \\ and Eko Hanudin ${ }^{* *}$ \\ "Faculty of Fishery and Marine Science, Department of Aquaculture, University of Riau \\ ${ }^{* *}$ Faculty of Agriculture, Department of Soil Science Gadjah Mada University \\ ${ }^{* *}$ Faculty of Agriculture, Department of Fishery, Gadjah Mada University
}

(Received 14 March 2011 ; Accepted 24 May 2011 )

\begin{abstract}
The pond bottom soil of Inceptisols mixed with Ultisols (I-U) and Vertisols (I-G) with the proportion of (70:30); (50:50); (30:70) showed the improvement of clay fractions $>30 \%$ compared with the control (100\% Inceptisols). These mixtures were given basal fertilizer (quail droppings manure with dosage of 2 tons/ha/month), Urea, and $\mathrm{SP}_{36}$. Cultivation system was divided into two stocked: fish ponds with $50 \mathrm{fish} / \mathrm{m}^{2}$ and ponds without fish. The best mix with the basal fertilizer was further treated with fertilization treatment ( 1 ton/ha/month of quail droppings manure) 3 times within 42 days of larval rearing. Physical and chemical soil analyses showed an increase of total soil porosity (>50\%), decrease of SG, BD, and permeability (medium), $\mathrm{pH}>5$, the CEC $>20 \mathrm{cmol}(+) \mathrm{kg}-1$, and the $\mathrm{C} / \mathrm{N}$ ratio $<6.5$. The proportion of the best mix of $30 \%$ $\mathrm{I}: 70 \% \mathrm{U}$ and $50 \% \mathrm{I}: 50 \% \mathrm{G}$ with 3 times of the fertilization frequency gave significant improvement of water quality, chlorophyll-a, diversity of plankton, benthic algae, fish growth, and total biomass. The presence of mineral montmorillonite on a mixture of $50 \%$ I : $50 \% \mathrm{G}$ was a very good sign of the bottom soil fertility.
\end{abstract}

KEYWORDS: Ultisols, Vertisols, pond fertility, montmorillonite, soil physical and chemical properties

\section{INTRODUCTION}

Expansion of economic prospects of the seed of red tilapia for consumption size $(>400$ $\mathrm{g} /$ fish) is still very promising. In Yogyakarta, the potential area available for fishery related business is around $3,133.50$ ha (fresh water); 650.0 ha (brackish water ponds); 4,630.20 ha (ponds); and 10,265.60 ha (paddy field). However, aquaculture practices use only $0.17 \%$, $8.92 \%, 19.76 \%$, and $12.0 \%$ of those resources respectively. Red tilapia seed production as published by Cangkringan Seed Board in the year of 2006 consisted of sizes: 1-5 cm: 41,000 fish; $5-8 \mathrm{~cm}: 431,905$ fish; 8 to $2 \mathrm{~cm}$ : 507 fish, (Watyandari, 2007). The seed production was still low, so that other methods to improve the production are needed such as increasing the suitability of pond bottom to support the availability of natural feed. Inceptisols located in Cangkringan is type of land dominated by sand fraction. Its texture is not suitable for pond bottom. In improving soil quality, basic infor-

\# Corresponding author. Faculty of Fishery and Marine Science, Department of Aquaculture, University of Riau, Jl. HR. Subrantas km 12,5, Pekanbaru, Riau, Indonesia. Tel.: +62 76165593 E-mail address: sabe_rinahs@yahoo.com; Phone : 08127557098 
mation of soil characteristics (physical, chemical, and mineralogy) is needed. However, this information is not available or very limited.

The low fertility of pond bottom soil (PBS) is caused by high content of sand fraction. In order to improve the fertility, mixing PBS with high clay soil is still being assessed and the best mixing proportion is not known. In addition, improving PBS fertility can also be done by adding with quail manure but the best application frequency has to be further studied.

PBS is one of several major environmental factors in fish farming, that can affect water quality and fish production. Sonnenholzner \& Boyd (2000), reported that pond productivity was determined by $\mathrm{pH}$ and concentration of organic material, nitrogen, and phosphorus in the soil. Nutrient concentrations and productivity of plankton in the water are associated with the $\mathrm{pH}$ and nutrient concentrations in the soil (Boyd, 1995; Boyd \& Munsiri, 1997).

Bowman (1992) in Egna \& Boyd (1997) classified soil pond based on the content of organic matter and the sources causing acidity and alkalinity of soil, namely 1 ) the soil reaction to $\mathrm{pH}$ (acid, neutral, and alkaline); and 2) soil composition that was actually related to the source of its acidity or alkalinity (cations exchanged vs free minerals), organic matter content (organic matter vs mineral soil), soil particle size distribution (sandy, coarse-loamy, fine-loamy, and clayey), and mineralogy of clay fraction $(1: 1,2: 1$, a mixture of clay minerals). In adding to soil $\mathrm{pH}$, the most important soil chemical characteristics in fish farming are CEC, $\mathrm{pH}$ relations with base saturation and nutrient limitation.

The aim of the research was to obtain mixture of texture classes of Inceptisols-Ultisols (I-U) and Inceptisols-Vertisols (I-G), which can affect the fertility of the pond bottom soil after addition of basal fertilizer and the frequent addition of quail droppings manure to improve the productivity of the pond of red tilapia (Oreochromis sp.) fries production.

\section{MATERIALS AND METHODS}

The research consists of two phases. The first phase is to find the best proportion of the mixture (I-U) and (I-G) from 6 treatments and control (70\%I : 30\%U; 50\% : 50\%U; 30\% : 70\%U; 70\% : 30\%G; 50\% : 50\%G; and 30\% : 70\%G;
$100 \%$ I) with 3 replications. 42 units of ponds with each sized of $1 \mathrm{~m} \times 2 \mathrm{~m} \times 1 \mathrm{~m}$ for were filled with those mixtures up to $15 \mathrm{~cm}$ thick. In each pond units, muddiness is performed, followed by basal fertilizer (quail droppings manure for 2 tons/ha/month), benthic algae growth (7-10 days of soil incubation) and urea $(45 \% \mathrm{~N})$ and $\mathrm{SP}_{36}(36 \% \mathrm{P})$ fertilization ratio $(6: 1)$. There were 2 treatments of cultivation system, namely the stocking of red tilapia larvae (Oreochromis sp.) in 21 pond units with the density of the $50 \mathrm{fish} / \mathrm{m}^{2}$ and the remaining was without fish. The second phase, the best mixture of I-G and I-U soil was given the fertilization treatment of 1 ton/ha/month of quail droppings manure as many as 1, 3, and 5 times within 42 days of larval rearing. Pond bottom soil and pond water were analyzed for their physical, chemical, and biological characteristics. Growth parameters for the fish including fish biomass, and fish total length, chlorophyll-a concentration, plankton density, and benthic algae were measured.

\section{Soil and Water Sampling}

The Ultisols, Vertisols, and Inceptisols were obtained from Purwokerto, Sentolo, and Cangkringan, Yogyakarta, Indonesia, respectively. All soils types were taken from $0-20 \mathrm{~cm}$ depth. The soil and quail manure (obtained from Godean) were dried naturally, grounded, and sieved ( $2 \mathrm{~mm}$ mesh size). Characteristics of soil used in this study were as follow: (1) Inceptisols (Cangkringan) : 12\% clay fraction; brown blackish color (10 YR 2/2); pH 5.2; smectite and kaolinite minerals, (2) Ultisols (Banyumas) : $60 \%$ clay fraction, dark drown reddish color (5 YR 3/6), pH 4.7; halloysite mineral, and (3) Vertisols = Grumusols (Sentolo) : $69 \%$ clay fraction, black color (10 YR 2/1), pH 6.7 , montmorillonite minerals. $\mathrm{pH}$ of water used to irrigate the ponds was 7.2. The water was stored in a concrete tank $(4.4 \mathrm{~m} \times 7.9 \mathrm{~m} \times 0.8$ $\mathrm{m})$. The pond bottom soil samples were obtained from $5 \mathrm{~cm}$ depth. Samples were taken from 3 sampling points using a PVC pipe ( $5 \mathrm{~cm}$ diameters). Soil samples were mixed (composited) and dried naturally. The dried samples were then sieved ( $2 \mathrm{~mm}$ mesh size) and stored in labelled plastic bags. Water samples were taken using sample bottles and then were stored on the plastic and dark glass bottles. These samples were then analysed in the laboratory. 


\section{Parameters of Soils, Water, and} Biological Analysis

The parameter of PBS quality included $\mathrm{pH}$ (measured using $\mathrm{H}_{2} \mathrm{O} 1: 5$, Boyd \& Tucker, 1992), soil texture and the permeability (measured using pipetting method, Black et al., 1965 and of the ICW Permeameter model), total porosity, Bulk Density (BD), and water content (measured using cylinder, and Graphymetric method (Black et al., 1965)), Specific Grafity (SG) (measured using piknometer), pore size distribution (measured using $\mathrm{pF} 0, \mathrm{pF} 1, \mathrm{pF} 1 / 3$, pF4.2 of the Pressure Plate Apparatus), N-Total (measured using Kjehdahl method), organic matter (measured using Walkey and Black method), $\mathrm{C} / \mathrm{N}$ ratio, and $\mathrm{P}$ available (measured using Bray \& Olsen) and the CEC and Base Saturation (measured using $1 \mathrm{~N} \mathrm{NH}_{4} \mathrm{OAC}$ extracted $(\mathrm{pH}=7)$ measured by AAS (Atomic Absorption Spectroscopy), Black et al., 1965.

Water quality measurement was conducted in situ. A Water Quality Checker (WQC-20) was used to measure dissolved oxygen, and $\mathrm{pH}$. DHL was measured using a Hanna Instruments $\mathrm{HI} 8819 . \mathrm{CO}_{2}$, total alkalinity and hardness were measured using titration method proposed by Boyd \& Tucker (1992).

The biological characteristics measured were chlorophyll-a concentration, plankton, benthic algae, and fish growth. Chlorophyll-a concentration was measured using monochromatic method (Lorenzen, 1967 in Wetzel \& Likens, 1991), compositions of plankton and benthic algae were identified using microscope (Davis, 1955; Mizuno, 1970; Shirota, 1966), abundance of plankton was calculated using SRCC method (Sedgwick Rafter Counting Chamber) with formula modification LDMC (Lackey Drop Microtransect Counting Method), abundance of benthic algae was calculated using modification Lackey Drop Microtransecting Methods (APHA, 1989). Fish parameters included total biomass $(\mathrm{g})$, total length (cm) was measured using the formula by Effendi (1979), the population Specific Growth Rates (SGR (\%) by Brown in Richter, 2001) and Metabolic Growth Rates (MGR; $\mathrm{g} \mathrm{kg}^{-0.8}$ day $^{-1}$ ) were therefore calculated for red tilapia using the formula proposed by De Silva \& Anderson (1995).

\section{Data Analysis}

Data obtained were then tabulated and analyzed using ANOVA and continued using
DMRT/Duncan's New Multiple Range Test (5\%) (Gomez \& Gomez, 1995). Data was analyzed statistically using computer program Proc. GLM in SAS/STAT.

\section{RESULTS AND DISCUSSION}

\section{Physical Quality of Pond Bottom Soil}

Increasing of clay content in PBS was from sandy loam (control) to clay (30\% : $70 \% \mathrm{U})$, and clay (30\%l : $70 \% \mathrm{G})$ increased in total of useful pore $(>0.20-3,000 \mu \mathrm{m})$ and total porosity decrease in unuseful pore, BD and SG of pond bottom soil. Figure 1 a showed that the sand and silt fraction of Inceptisols have been replaced by clay fractions in the proportion of the mixture (70:30), (50:50), (30:70) and the increase in total porosity, decrease in $\mathrm{BD}$ and SG from clay contained in Ultisols and Vertisols. In Figure lb, the increase in total porosity, and the decrease in BD and SG was more influenced by the content of organic matter (Table $1)$.

The increase of clay and organic matter content has also reduced the permeability of the Inceptisols soil. Figure $2 \mathrm{a}$ and $2 \mathrm{~b}$ showed that the permeability of PBS (control) ranged from 14.6 to $15.7 \mathrm{~cm} / \mathrm{hr}$ (fast) whereas, the highest clay fraction for $30 \% \mathrm{I}: 70 \% \mathrm{U}$ without and with fish treatment ranged from 5.0 to $5.5 \mathrm{~cm} /$ $\mathrm{hr}$ (medium) and 30\% : : 70\% G without and with fish ranged from 3.3 to $3.8 \mathrm{~cm} / \mathrm{hr}$ (medium).

The decrease in permeability was significant in 3 times fertility during 42 days rearing period. The permeability for $30 \% \mathrm{I}: 70 \% \mathrm{U}$ without and with fish ranged from 4.8 to $5.4 \mathrm{~cm} / \mathrm{hr}$ (medium) and 50\% I: 50\% G without and with fish ranged from 3.4 to $4.2 \mathrm{~cm} / \mathrm{hr}$ (medium) (Figure $2 \mathrm{~b}$ ). This condition was caused by the decrease of the percentage of unused pores as they were covered by suspended particles (organic and inorganic) during sedimentation process in the column. Yilmaz et al. (2005) proved that increase of clay and organic matter in saturity condition decreased BD and permeability. This condition was caused by soil containing of $\mathrm{Ca}^{2+}$ and $\mathrm{Mg}^{2+}$ in mineral smektit and kaolinite different.

In addition to different types of minerals that make up the Ultisols and Vertisols soil, soil pore size distribution is also different (Figure $3 a$ and $3 b$ ). The increasing of clay content of PBS also increased the total of useful pore $(>0.20 \mu \mathrm{m}-3,000 \mu \mathrm{m})$. In Phase Il the best use- 


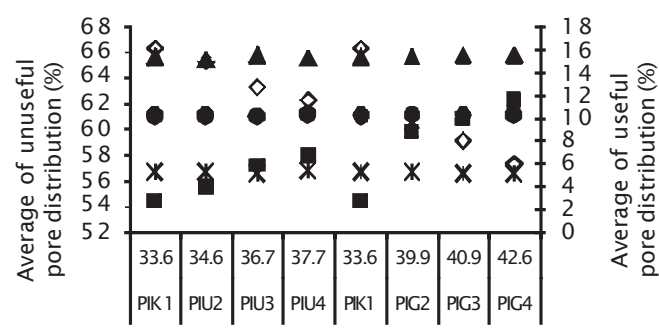

Total of useful pore (\%) in treatment $\mathrm{I}-\mathrm{U}$ and I-G

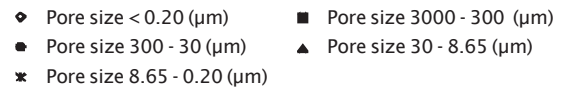

(a)

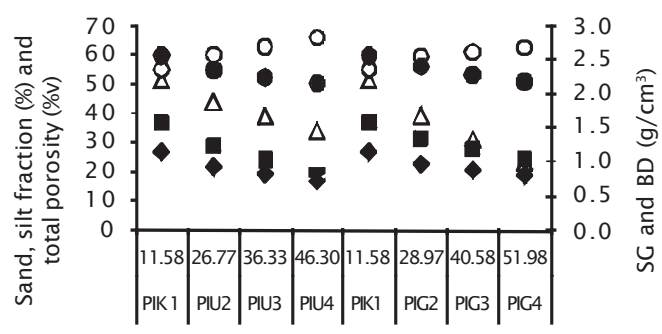

Clay fraction (\%) in treatment $\mathrm{I}-\mathrm{U}$ and $\mathrm{I}-\mathrm{G}$

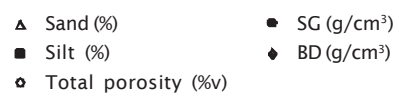

(b)

Figure 1. The effect of basal fertilizer in proportional combination of PBS toward distribution of unuseful and useful pore size (a) toward percentage of the fraction and total porosity (\%), SG and BD ( $\left.\mathrm{g} / \mathrm{cm}^{3}\right)$; (b). Pond bottom soil mixture proportion (in \%) were 100:0 (Control) (1), 70:30 (2), 50:50 (3), 30:70 (4) for Inceptisols-Ultisols (I-U) and InceptisolsVertisols (I-G) in Phase I studies

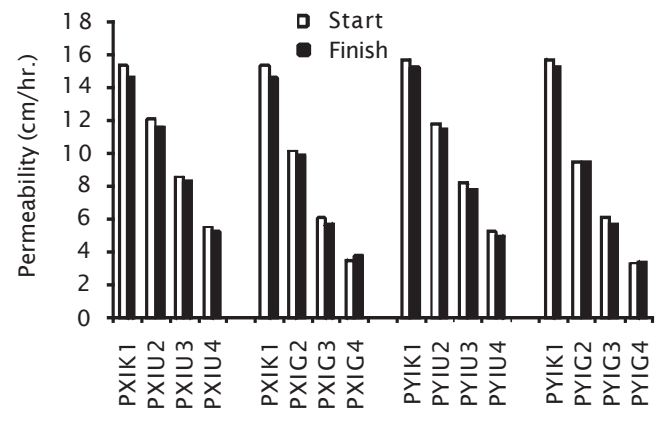

Proportion combination of treatments

(a)

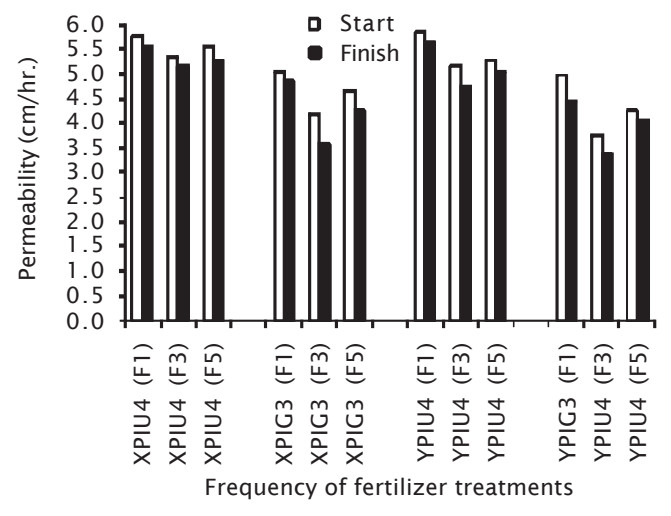

(b)

Figure 2. The effect of basal fertilizer in proportion combination of PBS in the research Part 1 (a) and frequency of fertilizer application in the research Part 2 (b) pond bottom soil permeability. Pond bottom soil mixture proportion (in \%) were 100:0 (Control) (1), 70:30 (2), 50:50 (3), 30:70 (4) for Inceptisols-Ultisols (U) and Inceptisols-Vertisols (G) with a cultivation system without spreading fish $(\mathrm{X})$ and with stocked fish $(\mathrm{Y})$, and in the fertilizer application frequency of F-1, F-3, and F-5

ful pore distribution in a cultivation system with stocked fish ranged from $36.6 \%$ to $39.3 \%$ of the $\mathrm{I}-\mathrm{U}$ mixture and ranged from $37.8 \%$ to $43.0 \%$ of the I-G mixture, whereas, the biggest unuseful pore distribution soil ranged from $60.7 \%$ to $63.4 \%$ of the I-U mixture and ranged from $57.0 \%$ to $62.0 \%$ of the I-G mixture. Information of soil pore size distribution is useful to determine the rate of decomposition of organic matter during the drying of ponds.

\section{Chemical Parameters of Pond Bottom Soil}

Table 1 showed that PBS chemical fertility was strongly influenced by soil $\mathrm{pH}$. Solubility of ions as nutrients was very useful to support the growth of natural food of red tilapia larvae. PBS pH I-U mixture was lower than I-G due to Ultisols soil material $\mathrm{pH}$ of greater that 5 . Buffer capacity role in increasing $\mathrm{pH}$ of the $\mathrm{I}-\mathrm{U}$ mixture was very dependable on alkali cations. 

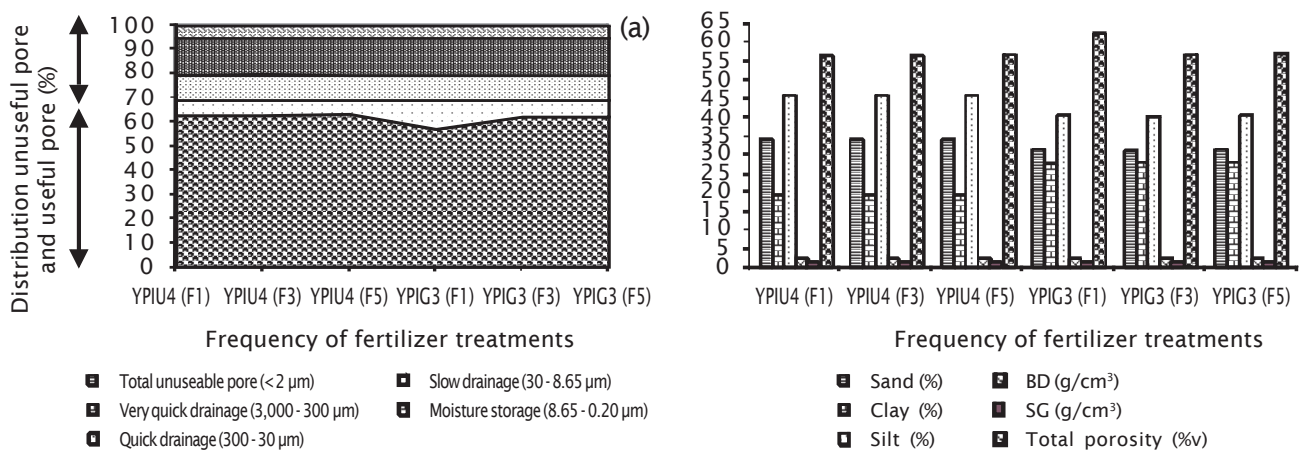

(b)

Figure 3. The effect of frequency of fertilizer application toward distribution of unuseful and useful pore size (a) and toward percentage of the fraction of sand, silt, clay, total porosity (\%), SG and BD ( $\left.\mathrm{g} / \mathrm{cm}^{3}\right)$ (b). Pond bottom soil mixture proportion (in \%) at 50:50 (3) and 30:70 (4) for Inceptisols-Ultisols (U) and Inceptisols-Vertisols (G) with a cultivation system without stocked fish $(\mathrm{X})$ and with stocked fish $(\mathrm{Y})$ and in the fertilizer application frequency of F-1, F-3, and F-5 in Phase II studies

Table 1 showed that organic matters presence in the pond bottom soil were originated from the applied fertilizer and these materials support the growth of benthic algae and phytoplankton population. The increase of chlorophyll-a in the pond indicated that the fertility of the pond was improved. Improvement of organic matter content in the control was around $1.64 \%-1.79 \%$, and was lower than in the mixed I-G (1.80\%-2.25\%) and I-U (1.82\%-2.15\%). High concentration of organic matter in the treated ponds was caused by the higher clay content in the mixed I-U. Soil Survey Staff (1990), stated that the typical level of organic matter content was $20 \%$ in the $0 \%$ clay, and it was $30 \%$ in the $50 \%$ or more.

Table 1. The average of pond bottom soil quality parameters in the research Part 1

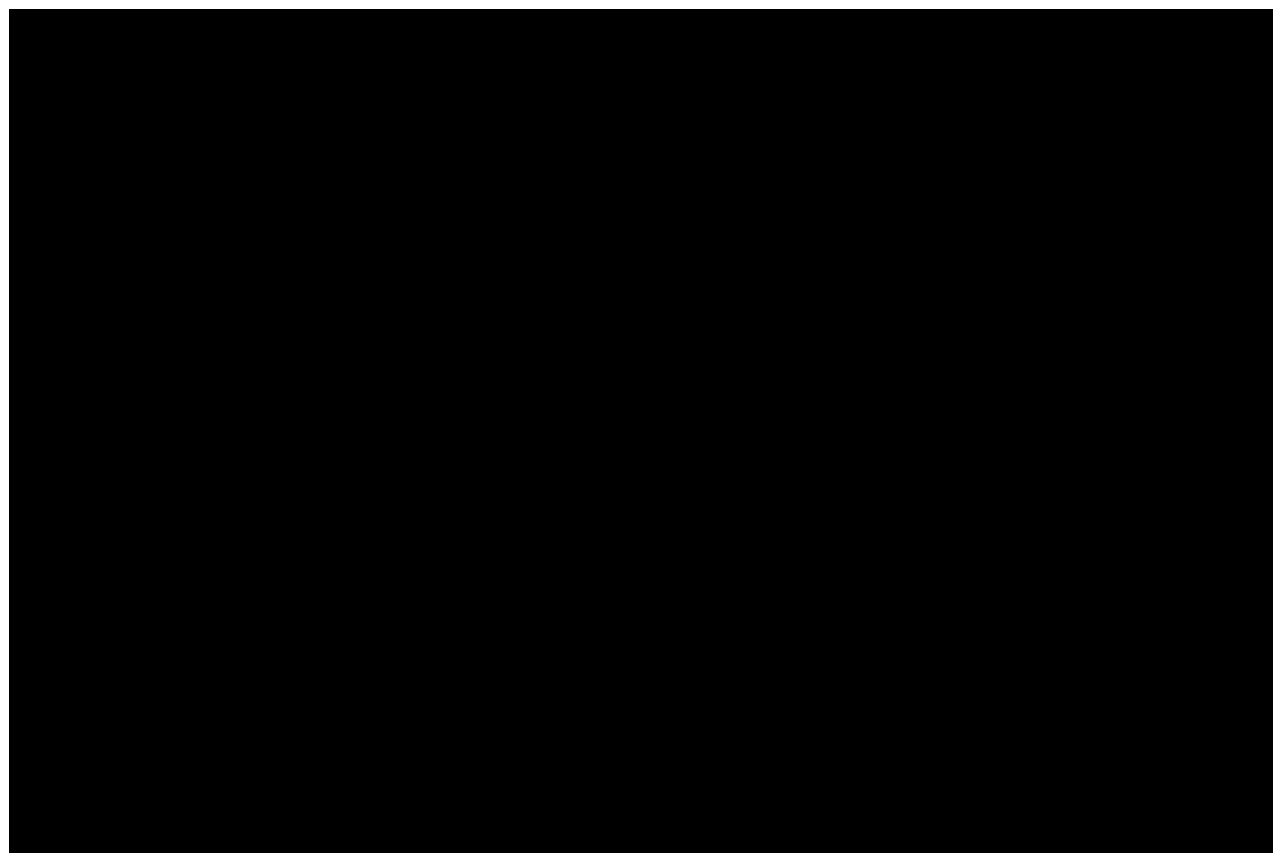

Numbers in the same column followed by the same letter are not significantly different (5\% DMRT) 
Table 2. The average of pond bottom soil quality parameters in research Part 2

\begin{tabular}{|c|c|c|c|c|c|c|}
\hline Treat ments & $\begin{array}{c}\text { Organic } \\
\text { matter (\%) }\end{array}$ & $\begin{array}{c}\text { N total } \\
(\%)\end{array}$ & $\begin{array}{c}\text { Ratio } \\
\mathrm{C} / \mathrm{N}\end{array}$ & $\begin{array}{c}\text { P-available } \\
\text { (mg/L) }\end{array}$ & $\begin{array}{c}\text { CEC } \\
\left(\mathrm{cmol}^{(+)} \mathrm{kg}^{-1}\right)\end{array}$ & $\begin{array}{c}\mathrm{pH} \\
\left(1: 5 \mathrm{H}_{2} \mathrm{O}\right)\end{array}$ \\
\hline \multicolumn{7}{|c|}{ Cultivation system without fish } \\
\hline $30 \% 1: 70 \% U(F-1)$ & $1.70^{\mathrm{ef}}$ & $0.24^{\mathrm{bc}}$ & $4.13^{f}$ & $0.263^{i}$ & $32.70^{d}$ & $5.25^{\mathrm{e}}$ \\
\hline $30 \% 1: 70 \% U(F-3)$ & $1.90^{\mathrm{cd}}$ & $0.25^{a b c}$ & $4.41^{\mathrm{ef}}$ & $0.315^{\mathrm{h}}$ & $33.69^{c}$ & $5.28^{\text {de }}$ \\
\hline $30 \% 1: 70 \% U(F-5)$ & $1.63^{f}$ & $0.19^{f}$ & $5.05^{\mathrm{cd}}$ & $0.242^{\mathrm{j}}$ & $30.54^{f}$ & $5.21^{\mathrm{e}}$ \\
\hline $30 \% 1: 70 \% G(F-1)$ & $2.36^{b}$ & $0.23^{\text {cde }}$ & $6.06^{a b}$ & $0.487^{c}$ & $33.40^{c}$ & $5.38^{d}$ \\
\hline $30 \% 1: 70 \% G(F-3)$ & $2.75^{\mathrm{a}}$ & $0.25^{\mathrm{abc}}$ & $6.41^{\mathrm{a}}$ & $0.537^{b}$ & $36.11^{\mathrm{a}}$ & $5.49^{c}$ \\
\hline $30 \% 1: 70 \% G(F-5)$ & $1.93^{\mathrm{cd}}$ & $0.20^{\text {ef }}$ & $5.60^{\mathrm{b}}$ & $0.455^{\mathrm{e}}$ & $31.33^{\mathrm{e}}$ & $5.31^{\mathrm{ed}}$ \\
\hline \multicolumn{7}{|c|}{ Cultivation system with fish } \\
\hline $30 \% 1: 70 \% U(F-1)$ & $1.81^{\mathrm{de}}$ & $0.25^{a b c}$ & $4.26^{\mathrm{ef}}$ & $0.417^{9}$ & $33.47^{c}$ & $5.30^{\text {de }}$ \\
\hline $30 \% 1: 70 \% U(F-3)$ & $1.96^{c}$ & $0.26^{\mathrm{ab}}$ & $4.38^{\mathrm{ef}}$ & $0.435^{f}$ & $35.15^{b}$ & $5.37^{d}$ \\
\hline $30 \% 1: 70 \% U(F-5)$ & $1.72^{\mathrm{ef}}$ & $0.21^{\mathrm{def}}$ & $4.77^{\mathrm{de}}$ & $0.264^{i}$ & $31.89^{e}$ & $5.26^{\text {de }}$ \\
\hline $30 \% 1:$ 70\%G (F-1) & $2.35^{b}$ & $0.25^{\mathrm{abc}}$ & $5.55^{b c}$ & $0.494^{c}$ & $34.59^{b}$ & $5.64^{a b}$ \\
\hline $30 \% 1: 70 \% G(F-3)$ & $2.86^{\mathrm{a}}$ & $0.27^{a}$ & $6.09^{\mathrm{ab}}$ & $0.555^{\mathrm{a}}$ & $36.68^{\mathrm{a}}$ & $5.72^{\mathrm{a}}$ \\
\hline $30 \% 1: 70 \% G(F-5)$ & $2.00^{c}$ & $0.23^{\mathrm{bcd}}$ & $5.05^{\mathrm{cd}}$ & $0.464^{d}$ & $33.83^{c}$ & $5.57^{\mathrm{bc}}$ \\
\hline
\end{tabular}

Numbers in the same column followed by the same letter are not significantly different (5\% DMRT)

In Table 1, the patterns show that the nutrient concentration of organic matter, $\mathrm{N}$-total, and available $P$ were increased with the addition of clay content where the nutrient content of I-G mixture was higher than the I-U. In the research Phase II (Table 2), fluctuations of nutrient concentrations were influenced by the frequency of fertilization. The highest CEC of pond bottom soil was found in 30\%l : $70 \% \mathrm{G}$ pond stocked with fish for $36.45 \mathrm{cmol}(+) \mathrm{kg}^{-1}$ and the lowest was in the control pond stocked with fish of $26.04 \mathrm{cmol}^{(+)} \mathrm{kg}^{-1}$ and without fish of $26.45 \mathrm{cmol}^{(+)} \mathrm{kg}^{-1}$. Soil CEC indicates the level of PBS fertility where the value depends on soil colloid quality type and quantity. This can be seen from the low given CEC values after which it increased significantly after the fertilization.

Boyd (1995) stated that soil containing 30\% smectite clay and $5 \%$ organic materials has CEC ranged from 35 to $40 \mathrm{cmol}(+) \mathrm{kg}^{-1}$. Soil containing 10\% kaolinite clay, 20\% iron and clay aluminium oxide, and $1 \%$ of organic matter have 3-4 CEC cmol (+) kg-1 (Boyd, 1995).

Ratios of $\mathrm{C} / \mathrm{N}$ greater that 5 found in the research Phase I were the control, $70 \%$ : $30 \% \mathrm{U}$ pond without and with stocked fish and Phase II was 50\% : $50 \% \mathrm{G}(\mathrm{F}-1),(\mathrm{F}-3),(\mathrm{F}-5)$ pond without and with stocked fish and 30\% : $70 \% \mathrm{U}(\mathrm{F}-5)$ pond without stocked fish. Ratio of $\mathrm{C} / \mathrm{N}$ typically ranged from 10 to 20, but Boyd et al. (1997) found that on the CRSP research, the $\mathrm{C} / \mathrm{N}$ ranged from 7 to 15 (Munsiri et al., 1995). A study conducted by the Center of Auburn University of Alabama found that the ratio of $\mathrm{C} / \mathrm{N}$ was ranged from 5 to 7 . However, the overall ratio of $\mathrm{C} / \mathrm{N}$ was still below limits for the decomposition of organic matter to happen quickly.

\section{Pond Water Quality}

In ponds located in tropical area, water temperature is an important factor that has immediate effect to fish growth. Water temparature affects the chemical and biological processes occurring in the pond. In this research, pond water temperature ranged from $20.7^{\circ} \mathrm{C}$ to $32.7^{\circ} \mathrm{C}$ (Table 3 ) and ranged from $23.0^{\circ} \mathrm{C}$ to $33.3^{\circ} \mathrm{C}$ (Table 4). These temperature were still suitable for supporting the growth of red tilapia larvae, as well as the plankton, whereas the optimum temparature range for plankton growth ranges are from $20^{\circ} \mathrm{C}$ to $30^{\circ} \mathrm{C}$ (Effendi, 2003).

From the morning to the afternoon, water temperature variation was around $10^{\circ} \mathrm{C}$ (Table 
3 and Table 4). This variation had caused the rise of aquatic organism's oxygen consumption, 2-3 times higher. In the pond bottom soil that was treated with basal fertilizer, the DO was around 3.3-9.1 mg/L and the ponds bottom soil that were treated with frequent basal fertilizer, the DO decreased into $2.1-8.0 \mathrm{mg} / \mathrm{L}$ (Table 3 and Table 4). The low of $\mathrm{O}_{2}$ concentration in the morning may have been be caused by the presence of microorganisms that consumed oxygen for organic matter decomposition and inorganic matter oxidation. In contrast, increase of $\mathrm{O}_{2}$ in day time was caused mainly by photosynthetic processes conducted by phytoplankton presence in the water. Boyd (1990) predicted that in the $1.0-5.0 \mathrm{mg} / \mathrm{L}$ of $\mathrm{O}_{2}$ concentration, fish may still be alive, and grow better in water with oxygen concentration more than $0.5 \mathrm{mg} / \mathrm{L} \mathrm{O}_{2}$.

Relationship among $\mathrm{CO}_{2}$, alkalinity, hardness, and $\mathrm{pH}$ in the research Part 1 and 2 suggested that the pond bottom soil condition was suitable for supporting the growth of fish. $\mathrm{pH}$ of the pond water ranged from 6.2 to 8.7 and ranged from 6.2 to 8.4 , which tended to be lower in the morning and higher in the afternoon. $\mathrm{CO}_{2}$ concentration, however, was higher in the $\mathrm{pH}$ condition of 4 and it indicated the presence of anorganic carbon in the form of

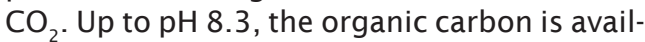
able in the form of $\mathrm{HCO}_{3}$. This carbonic ion plays as a buffer and provides carbon element for phytoplankton and benthic algae photosynthetic processes. Even though the $\mathrm{CO}_{2}$ was relatively high, the water was still suitable for fish culture, as $\mathrm{O}_{2}$ concentration was good. Boyd (1990) and Wurts \& Durborow (1992) stated that $\mathrm{CO}_{2}$ concentration that is suitable for fish population growth was $<5 \mathrm{mg} / \mathrm{L}$ and in the natural column may reach 5-10 mg/L.

Total alkalinity in the research Part 1 and 2 ranged as follows: the lowest were found in the control on cultivation system without stocked fish (81.7-105.7 mg/ $\mathrm{L} \mathrm{CaCO}_{3}$ ) and with stocked fish (89.2-127.8 mg/L CaCO${ }_{3}$ ), while the highest treatments were $30 \% 1: 70 \% \mathrm{U}$ the pond with fish (108.7-136.2 mg/ $\left./ \mathrm{CaCO}_{3}\right)$ and 50\% : $50 \% \mathrm{G}$ the pond with fish (103.7-130.2 $\mathrm{mg} / \mathrm{L} \mathrm{CaCO}_{3}$ ) and 50\%l : 50\%G (F-3) the pond with fish (87.0-120.80 mg/ $\mathrm{L} \mathrm{CaCO}_{3}$ ) and without fish (80.30-115.2 mg/ $\mathrm{L} \mathrm{CaCO}_{3}$ ).

The mixed PBS I-U, showed that the higher Ultisols concentration, the lower the hardness

Table 3. The average of pond water quality parameters in research Part 1 
Table 4. The average of pond water quality parameters in research Part 2

\begin{tabular}{|c|c|c|c|c|c|c|c|}
\hline Treat ments & $\begin{array}{l}\text { Temperat ure } \\
\left({ }^{\circ} \mathrm{C}\right)\end{array}$ & $\begin{array}{c}\mathrm{O}_{2} \\
(\mathrm{mg} / \mathrm{L})\end{array}$ & pH & $\begin{array}{c}\text { DHL } \\
(\mu \mathrm{S} / \mathrm{cm})\end{array}$ & $\begin{array}{c}\mathrm{CO}_{2} \\
(\mathrm{mg} / \mathrm{L})\end{array}$ & $\begin{array}{l}\text { Total } \\
\text { alkalinity } \\
\text { (mg/L) }\end{array}$ & $\begin{array}{c}\text { Total } \\
\text { hardness } \\
(\mathrm{mg} / \mathrm{L})\end{array}$ \\
\hline \multicolumn{8}{|c|}{ Cultivation system without fish } \\
\hline $30 \% 1: 70 \% \mathrm{U}(\mathrm{F}-1)$ & $23.0-33.3$ & $2.2-7.5$ & $6.3-8.2$ & $226.7-241.3$ & $6.2-7.9$ & $71.5-93.0$ & 135.7-192.9 \\
\hline $30 \% 1: 70 \% U(F-3)$ & $23.0-33.3$ & 2.4-7.6 & $6.4-8.4$ & $240.7-253.0$ & $6.3-7.3$ & $77.2-106.8$ & $138.1-198.8$ \\
\hline $30 \% 1: 70 \% \cup(F-5)$ & $23.0-33.3$ & $2.1-7.4$ & $6.4-8.3$ & $234.0-245.7$ & $6.9-7.8$ & $69.2-90.8$ & 132.1-194.1 \\
\hline $30 \% 1: 70 \% G(F-1)$ & $23.0-33.3$ & 2.3-7.6 & $6.2-8.4$ & $253.7-266.7$ & $5.3-7.6$ & $78.5-108.8$ & $148.8-188.1$ \\
\hline $30 \% 1: 70 \% \mathrm{G}(\mathrm{F}-3)$ & $23.0-33.0$ & 2.4-7.9 & $6.5-8.4$ & $249.0-262.0$ & $5.4-7.3$ & $80.3-115.2$ & $150.0-195.2$ \\
\hline $30 \% 1: 70 \% G(F-5)$ & $23.0-33.0$ & $2.1-7.7$ & $6.2-8.4$ & $237.0-245.3$ & $6.6-7.5$ & 73.7-107.0 & 146.4-186.9 \\
\hline \multicolumn{8}{|c|}{ Cultivation system with fish } \\
\hline $30 \% 1: 70 \% \mathrm{U}(\mathrm{F}-1)$ & $23.0-33.0$ & $2.2-7.5$ & $6.3-8.3$ & $238.0-250.0$ & $6.9-7.5$ & $75.5-102.5$ & $121.4-178.6$ \\
\hline $30 \% 1: 70 \% U(F-3)$ & $23.0-32.7$ & $2.3-7.8$ & $6.7-8.4$ & $241.0-257.3$ & $6.6-7.8$ & $79.5-119.5$ & $128.6-183.3$ \\
\hline $30 \% 1: 70 \%$ U (F-5) & $23.0-33.0$ & $2.1-7.7$ & $6.4-8.4$ & $241.0-249.3$ & $6.8-7.3$ & $71.0-96.5$ & $116.7-177.4$ \\
\hline $30 \% 1: 70 \% G(F-1)$ & $23.0-33.3$ & $2.2-7.7$ & $6.6-8.4$ & $259.3-272.3$ & 7.3-7.6 & $82.7-107.7$ & 161.9-197.6 \\
\hline 30\%l : 70\%G (F-3) & $23.0-33.0$ & $2.3-8.0$ & $6.7-8.5$ & $255.0-268.3$ & $6.3-7.3$ & $87.0-120.8$ & $173.8-202.4$ \\
\hline $30 \% 1: 70 \% \mathrm{G}(\mathrm{F}-5)$ & $23.0-33.3$ & $2.1-7.8$ & $6.6-8.4$ & $248.0-256.7$ & $6.6-7.4$ & $74.8-97.0$ & 155.9-194.1 \\
\hline
\end{tabular}

concentration would be. In the mixed I-G, however, as the Vertisols concentration increased, the hardness also increased. The hardness concentration in each plot (Research Part 1 and 2) ranged as follow: the lowest were found in controls on cultivation system with stocked fish (1 19.1-148.8 mg/L CaCO ${ }_{3}$ ), 30\% : $70 \% \mathrm{U}$ the pond without stocked fish (121.4-144.6 mg/L $\mathrm{CaCO}_{3}$ ) and $30 \% 1: 70 \% \mathrm{U}(\mathrm{F}-5)$ with stocked fish (1 16.7-177.4 mg/ $\mathrm{L} \mathrm{CaCO}_{3}$ ), while the highest were $50 \% 1$ : $50 \% \mathrm{G}$ the pond without stocked fish (142.9-164.3 mg/ $\mathrm{LCaCO}_{3}$ ) and with stocked fish (140.5-167.9 mg/L CaCO $)$, and 50\% : 50\%G (F-3) with stocked fish (173.8-202.4 mg/L $\mathrm{CaCO}_{3}$ ). This condition occurred as $\mathrm{Ca}$ content in the Vertisols was higher than that of the Inceptisols and Ultisols. In the research Part 2, however, increase of Ca concentration in the mixed I-U was an effect of frequent fertilizer application (quail manure). Boyd (1990) stated that the medium total alkalinity concentration $(75-200 \mathrm{mg} / \mathrm{L})$ and the hardness ranged from 100 to $250 \mathrm{mg} / \mathrm{L} \mathrm{CaCO}_{3}$, were good for supporting the fish life. This condition is also supported by high conductivity (DHL) $(<1,500 \mathrm{uS} /$ $\mathrm{cm}$ ), numerically describes the ability of water in conducting electricity. Source of electrical conductor can be derived from acid, alkali and salt (Effendi, 2003).

\section{Pond Productivity}

Improvement of pond productivity can be identified by the increase of chlorophyll-a content, plankton density and red tilapia biomass growth. In the ponds with and without stocked fish, productivity improvement in the ponds with mixed (30\%l : $70 \% \mathrm{U})$ and $(50 \% 1: 50 \% \mathrm{G})$ was significantly higher than those of the controls (5\% DMRT) (Table 5).

By the end of the research, chlorophyll-a concentration, plankton and benthic algae density, total biomass and length of red tilapia reared in the best treated ponds $30 \% 1$ : $70 \% \mathrm{U}$ of ponds without and with stocked fish, 50\%l : $50 \% \mathrm{G}$ of ponds without and with stocked fish, and control pond without and with stocked fish were 11.12-13.07 chl.a $\mu \mathrm{g} / \mathrm{L}, 12.01-16.09 \mathrm{chl} . \mathrm{a}$ $\mu \mathrm{g} / \mathrm{L}, 3.72-4.61 \mathrm{chl} . \mathrm{a} \mu \mathrm{g} / \mathrm{L} ; 4,265-5,848$ cells/ $\mathrm{mL} ; 5,450-6,285$ cells/mL; $1,730-3,835$ cells/ $\mathrm{mL} ; 6,798-9,108$ cells/cm²; 7,601-14,190 cells/ $\mathrm{cm}^{2} ; 2,640-4,554$ cells $/ \mathrm{cm}^{2} ; 115.42 \mathrm{~g} ; 99.51 \mathrm{~g}$; $49.77 \mathrm{~g} ; 5.0 \mathrm{~cm} ; 4.6 \mathrm{~cm}$; and $3.8 \mathrm{~cm}$ respectively (Table 5 and 7). Addition of basal fertilizer to clay content $(46.08 \%-46.30 \%, 40.13 \%$ $40.58 \%$, and $11.38 \%-11.58 \%$ ) to mix the pond bottom soil (30\%l : $70 \% \mathrm{U}),(50 \% \mathrm{l}: 50 \% \mathrm{G})$, and control (100\% I) did not show maximum result. Therefore another treatment, namely frequent 
Table 5. Pond fertility based on chlorophyll-a content, plankton and benthic algae density harvested in the $40^{\text {th }}$ day of the research Part 1

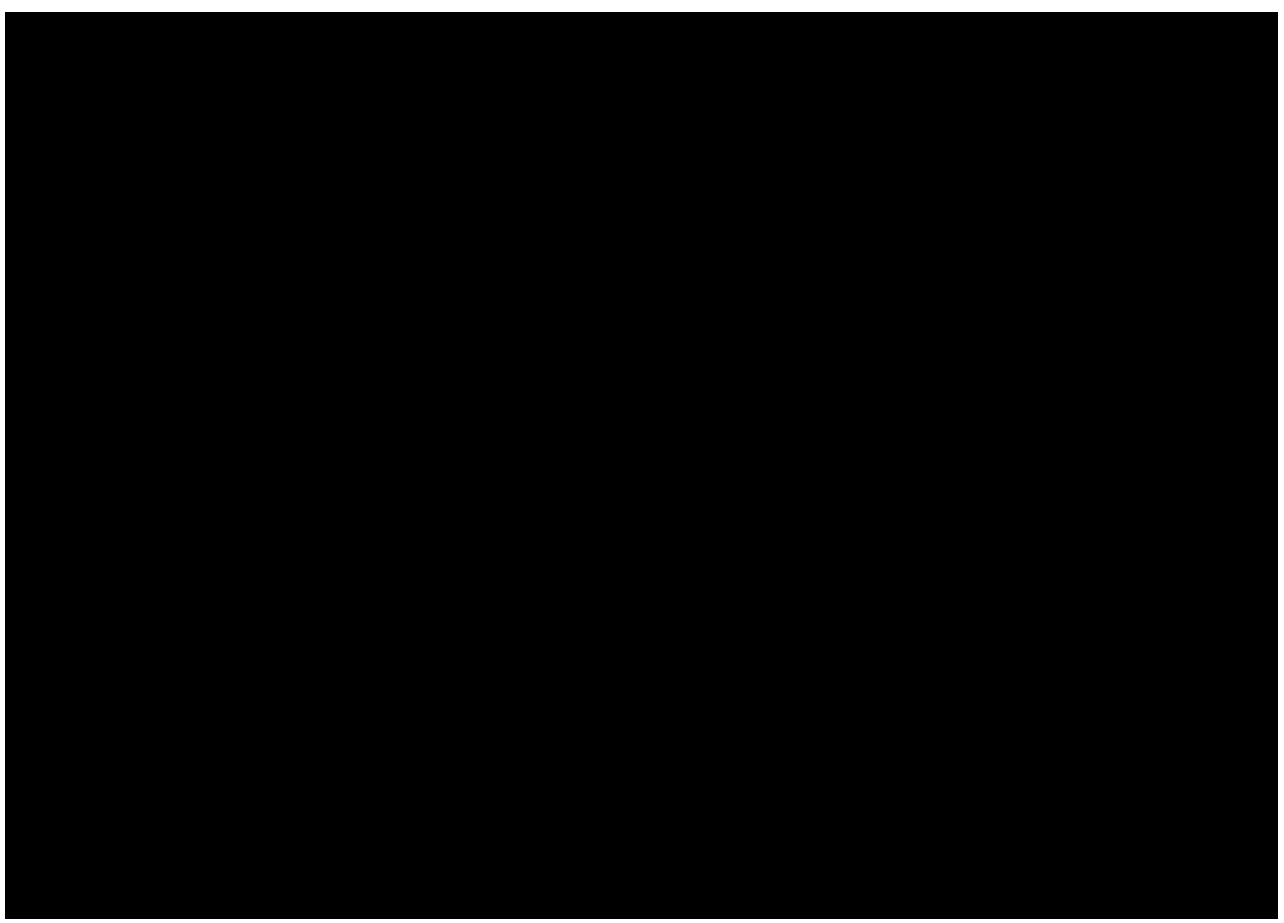

Numbers in the same column followed by the same letter are not significantly different (5\% DMRT)

fertilizer addition was applied. The frequencies of fertilizer addition applied in this research were 1,3 , and 5 times during the period of larval rearing (42 days).

The best soil combination (30\% : $70 \% \mathrm{U})$ and (50\% : $50 \% \mathrm{G})$ were fertilized 3 times, and the results were ranged as follows: 15.02-18.10 chl.a $\mu \mathrm{g} / \mathrm{L}$ and $17.11-20.56 \mathrm{chl} . \mathrm{a} \mu \mathrm{g} / \mathrm{L}$ (chlorophyll-a); 5,955-8, 140 cells/mL and 7,560-8,740 cells $/ \mathrm{mL}$ (plankton density) and 9,469-12,562 cells $/ \mathrm{cm}^{2}$ and 10,516-19,734 cells $/ \mathrm{cm}^{2}$ (benthic algae density) (Table 6). Eventhough they were not significant, the results of chlorophyll-a measurement showed that the improvement pond fertility was related to the increase of clay materials and this fertility improvement was positively correlated to fish weight gain. The highest total biomass of the fish was $188.04 \mathrm{~g}$ (30\% : $70 \% \mathrm{U})$ (F-3) and $217.35 \mathrm{~g}$ (50\%l : $50 \% \mathrm{G})(\mathrm{F}-3)$, respectively. The growth of fish in the pond treatments $(30 \% \mathrm{l}: 70 \% \mathrm{U})(\mathrm{F}-3)$ and $(50 \% \mathrm{l}: 50 \% \mathrm{G})(\mathrm{F}-3)$ were average of fish length $(5.2 \mathrm{~cm}$ and $5.7 \mathrm{~cm})$, respectively. Specific growth rate $(13.6 \%$ and $14.3 \% \mathrm{BW} /$ day $)$, and metabolic rate $\left(14.38\right.$ and $15.15 \mathrm{~g} \mathrm{~kg}^{-0.8} /$ day) respectively, however, was significant ( $5 \%$ DMRT) (Table 8).

Growth of plankton and benthic algae served as the natural food of red tilapia larvae can be predicted by the increase of chlorophyll-a concentration in the pond water. In the research Part 1 and Part 2, the value of chlorophyll-a concentration indicated that the pond was fertile. Sen \& Sonmez (2006) that worked on seasonal variation of algae in the fish pond, stated that "if the average of chlorophyll-a concentration in a pond is $5 \mu \mathrm{g} / \mathrm{L}$, algae growth in that pond is low".

\section{CONCLUSION}

Inceptisols soil fertility as the mixing results of Ultisols (I-U) and Vertisols (I-G) with the proportion of (50:50) and (30: 70) showed the clay fractions improvement toward the ideal of $>30 \%$ compared with the controls $(100 \%$ Inceptisols). Soil mixing resulted in the increase of total porosity $>50 \%$, decrease in BD and SG, and permeability (medium). The use of 
Table 6. Pond fertility based on chlorophyll-a content, plankton and benthic algae density harvested in the $40^{\text {th }}$ day of the research Part 2

\begin{tabular}{|c|c|c|c|}
\hline \multirow[b]{2}{*}{ Treat ments } & \multicolumn{3}{|c|}{ Averange } \\
\hline & $\begin{array}{c}\text { Chlorophyll-a } \\
\text { concent ration }\left(\mathrm{mg} / \mathrm{m}^{3}\right)\end{array}$ & $\begin{array}{l}\text { Plankt on density } \\
\text { (cells } / \mathrm{mL})\end{array}$ & $\begin{array}{c}\text { Bent hic algae } \\
\text { density }(\text { cells } / \mathrm{mL})\end{array}$ \\
\hline \multicolumn{4}{|c|}{ Cultivation system without fish } \\
\hline $30 \% 1: 70 \% U(F-1)$ & $12.10^{j}$ & $5,145^{j}$ & $8,239^{j}$ \\
\hline $30 \% 1:$ 70\%U (F-3) & $15.02^{f}$ & $5,955^{h}$ & $9,460^{h}$ \\
\hline $30 \% 1: 70 \% U(F-5)$ & $13.05^{i}$ & $4,620^{k}$ & $7,392^{k}$ \\
\hline 30\%l : 70\%G (F-1) & $14.12^{\mathrm{g}}$ & $6,555^{f}$ & $9,176^{i}$ \\
\hline $30 \% 1: 70 \% G(F-3)$ & $17.11^{\mathrm{d}}$ & $7,560^{c}$ & $10,516^{f}$ \\
\hline $30 \% 1: 70 \% G(F-5)$ & $15.59^{\mathrm{e}}$ & $5,950^{h}$ & $8,250^{j}$ \\
\hline \multicolumn{4}{|c|}{ Cultivation system with fish } \\
\hline $30 \% 1: 70 \% U(F-1)$ & $13.58^{\mathrm{h}}$ & $7,095^{d}$ & $11,088^{\mathrm{e}}$ \\
\hline $30 \% 1: 70 \% \mathrm{U}(\mathrm{F}-3)$ & $18.10^{c}$ & $8,140^{b}$ & $12,562^{d}$ \\
\hline $30 \% 1: 70 \% \cup(F-5)$ & $16.00^{\mathrm{e}}$ & $6,330^{9}$ & $9,856^{9}$ \\
\hline $30 \% 1: 70 \% G(F-1)$ & $18.26^{c}$ & $7,575^{c}$ & $17,225^{b}$ \\
\hline 30\%l : 70\%G (F-3) & $20.56^{\mathrm{a}}$ & $8,740^{\mathrm{a}}$ & $19,734^{a}$ \\
\hline 30\%l : 70\%G (F-5) & $19.15^{b}$ & $6,845^{e}$ & $15,213^{c}$ \\
\hline
\end{tabular}

Numbers in the same column followed by the same letter are not significantly different (5\% DMRT)

Table 7. The average of weight, total weight, length, specific growth rate and metabolic rates of red tilapia larvae in the research Part 1

\begin{tabular}{|c|c|c|c|c|c|c|}
\hline \multirow{2}{*}{ Treat ment s } & \multicolumn{2}{|c|}{$\begin{array}{c}\text { The average of } \\
\text { fish weight } \\
(\mathrm{g})\end{array}$} & \multirow{2}{*}{$\begin{array}{c}\begin{array}{c}\text { Total } \\
\text { biomass } \\
(\mathrm{g})\end{array} \\
\begin{array}{c}\text { By the end } \\
\text { of the }\end{array} \\
\text { research }\end{array}$} & \multirow{2}{*}{$\begin{array}{c}\text { The average } \\
\text { of fish } \\
\text { lengt } \mathrm{h}(\mathrm{cm}) \\
\begin{array}{c}\text { By the end } \\
\text { of the } \\
\text { research }\end{array}\end{array}$} & \multicolumn{2}{|c|}{$\begin{array}{l}\text { Growth rate } \\
\text { (measured in } \\
\text { the } 42^{\text {th }} \text { day) }\end{array}$} \\
\hline & $\begin{array}{l}7 \text { days } \\
\text { old }\end{array}$ & $\begin{array}{l}\text { The end } \\
\text { of } \\
\text { research }\end{array}$ & & & $\begin{array}{c}\text { Specific } \\
\text { (\%BW/day) }\end{array}$ & $\begin{array}{c}\text { Metabolic } \\
\left(\mathrm{g} \mathrm{kg}^{-0,8} / \text { day }\right)\end{array}$ \\
\hline $100 \%$ & $0.009^{a}$ & $1.10^{\mathrm{e}}$ & $49.77^{d}$ & $3.8^{\mathrm{d}}$ & $11.36^{c}$ & $11.82^{\mathrm{e}}$ \\
\hline $70 \% 1: 30 \% U$ & $0.010^{\mathrm{a}}$ & $1.28^{\mathrm{de}}$ & $69.48^{\mathrm{cd}}$ & $4.2^{c}$ & $11.65^{b c}$ & $12.22^{\mathrm{de}}$ \\
\hline $50 \% 1: 50 \% U$ & $0.008^{a}$ & $1.68^{\mathrm{bc}}$ & $78.24^{b c}$ & $4.3^{c}$ & $12.64^{a}$ & $13.00^{b c}$ \\
\hline $30 \% 1: 70 \% U$ & $0.010^{\mathrm{a}}$ & $2.25^{\mathrm{a}}$ & $115.42^{a}$ & $5.0^{\mathrm{a}}$ & $12.80^{\mathrm{a}}$ & $13.80^{\mathrm{a}}$ \\
\hline $70 \% 1: 30 \% G$ & $0.009^{a}$ & $1.46^{\mathrm{cd}}$ & $68.74^{\mathrm{cd}}$ & $4.2^{\mathrm{c}}$ & $12.23^{\mathrm{ab}}$ & $12.63^{\mathrm{cd}}$ \\
\hline $50 \% 1: 50 \% G$ & $0.009^{a}$ & $1.96^{\mathrm{ab}}$ & $99.51^{\mathrm{ab}}$ & $4.6^{\mathrm{b}}$ & $12.83^{a}$ & $13.44^{\mathrm{ab}}$ \\
\hline 30\%l : 70\%G & $0.010^{\mathrm{a}}$ & $1.76^{\mathrm{bc}}$ & $79.40^{b c}$ & $4.5^{b c}$ & $12.32^{\mathrm{ab}}$ & $13.11^{b c}$ \\
\hline
\end{tabular}

Numbers in the same column followed by the same letter are not significantly different (5\% DMRT)

basal fertilizer improved chemical fertility $\mathrm{pH}$ $>5$, the CEC $>20 \mathrm{cmol}^{(+)} \mathrm{kg}^{-1}$, and the ratio C/ $\mathrm{N}<6.5$. The proportion of the best mix of $30 \%$ I: $70 \% \mathrm{U}$ and $50 \% 1: 50 \% \mathrm{G}$ with the frequency of fertilization 3 times gave significant improve- ment on water quality, chlorophyll-a, diversity of plankton, benthic algae, fish growth, and total biomass. The presence of mineral montmorillonite in a mixture of 50\% : 50\%G showed a very good result for the bottom soil fertility. 
Table 8. The average of weight, total weight, length, specific growth rate and metabolic rates of red tilapia larvae in the research Part 2

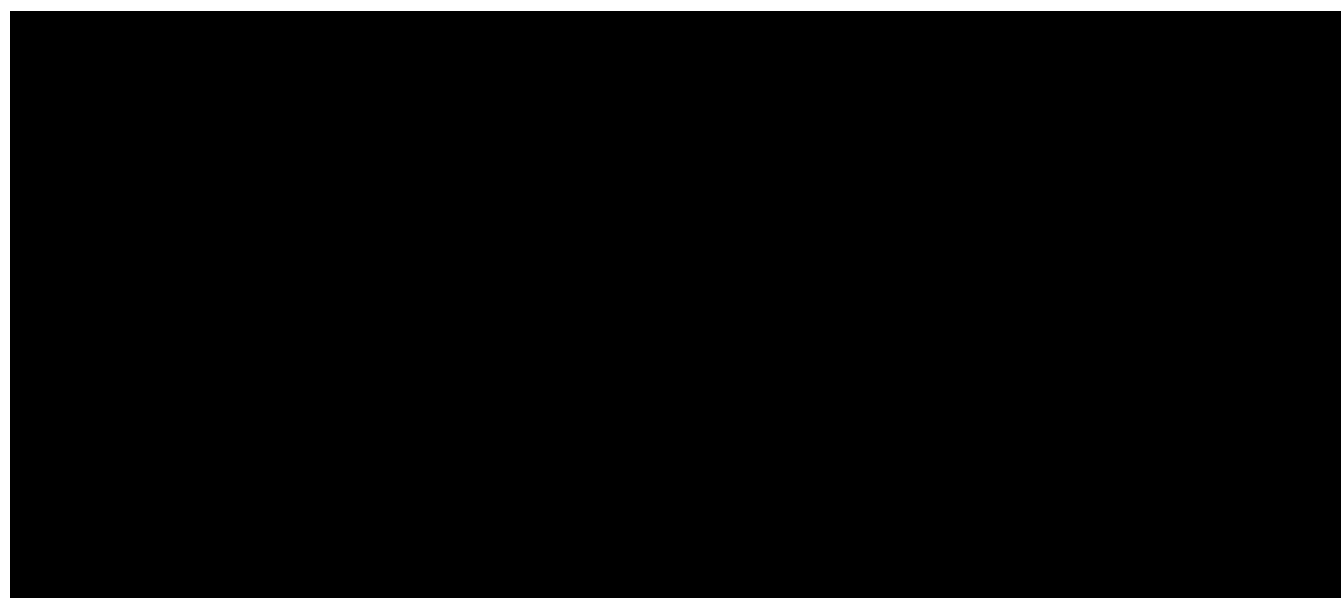

Numbers in the same column followed by the same letter are not significantly different (5\% DMRT)

\section{ACKNOWLEDGMENTS}

The authors would like to thank Mr. Ismangil for his help during Ultisols soil sampling in Banyumas and Mita during Vertisols soil sampling in Sentolo, Kulon Progo Regency. The authors also thanks Mr. Sudi for his help in hatching red tilapia larvae so that the seed supply could maintained for the research.

This research was partly funded by PT Chevron Pacific Indonesia from 2006 to 2008 and continued with doctoral Grants from LPPM GMU in 2009. For extraordinary support and material help, the authors would like to thank to other parties and individuals who directly and indirectly have taken part in this research.

\section{REFERENCES}

APHA. 1989. Standard Methods for the Examination of Water and Wastewater. Sixteenth Edition. American Public Health Association, American Water Works Association, and Water Pollution Control Federation, Washington, D.C., 1,268 pp.

Black, C.A., Evans, D.D., White, J.L., Ensminger, L.E., \& Clark, F.E. 1965. Method of Soil Analysis Part 1 and 2. American Society of Agronomy, Inc., Publisher Madison, Wisconsin, USA, 1,572 pp.

Boyd, C.E. 1990. Water Quality in Ponds for Aquaculture. Alabama Agriculture Experiment Station, Auburn University. Alabama, $482 \mathrm{pp}$.
Boyd, C.E. \& Tucker, C.S. 1992. Water Quality and Pond Soil Analyses for Aquaculture. Alabama Agriculture Experiment Station, Auburn University. Alabama, $181 \mathrm{pp}$.

Boyd, C.E. 1995. Bottom Soils, Sediment, and Pond Aquaculture. Chapman and Hall, New York, New York, 348 pp.

Boyd, C.E. \& Munsiri, P. 1997. Water Quality in Laboratory Soil-Water Microcosms with Soils from Different Areas of Thailand. J. of The World Aquaculture Society, 28: 165170.

Boyd, C.E., Queiroz, J., \& Wood, C.W. 1997. Pond Soil Characteristics and Dynamics of Soil Organic Matter and Nutrients. In: Burke, D., Baker, J., Goetze, B., Clat, D., \& Egna, H. (Editors), Fifteenth Annual Technical Report, 1996-1 997. Pond Dynamics/Aquaculture CRSP, Office of International Research and Development, Oregon State University, Corvallis, Oregon, p. 11-25.

Davis, C.C. 1955. The Marine and Fresh Water Plankton. Michigan State University Press, $369 \mathrm{pp}$.

De Silva, S.S. \& Anderson. T.A. 1995. Fish Nutrition in Aquaculture. Chapman and Hall. London, Glasgow, Weinheim, New York, Tokyo, Melbourne, Madras, $319 \mathrm{pp}$.

Effendi, M.I. 1979. Metode Biologi Perikanan. Cetakan Pertama. Yayasan Dewi Sri.Bogor, $163 \mathrm{pp}$.

Egna, S.H. \& Boyd, C.E. 1997. Dynamics of Pond Aquaculture. CRC Press LLC, 151 pp. 
Effendi, H. 2003. Telaah Kualitas Air Bagi Pengelola Sumber Daya dan Lingkungan Perairan. Penerbit Kanisius, 258 pp.

Gomez, K.A. \& Gomez, A.A. 1995. Statistical Procedure for Agriculture Research with Emphasis on Rice. The International Rice Research Institute. Philippines, 293 pp.

Mizuno, T. 1970. Illustrations of The Freshwater Plankton of Japan. Hoikusha Publishing Co., $351 \mathrm{pp}$.

Munsiri, P., Boyd, C.E., \& Hajek, B.J. 1995. Physical and Chemical Characteristics of Bottom Soil Profiles in Ponds at Auburn, Alabama, USA, and a Proposed Method for Describing Pond Soil Horizons. J. World Aquacult. Soc., 26: 346-377.

Richter, H. 2001. Seasonal Variation in Growth, Quantitative and Qualitative Food Consumption of Milkfish, (Chanos chanos Forsskal, 1775), and Nile tilapia, (Oreochromis niloticus L., 1758), in Laguna de Bay, Philippines. Dissertation. Aus dem Institut für Tierproduktion in den Tropen und Subtropen der Universität Hohenheim Fachgebiet Tierernährung und Aquakultur, $139 \mathrm{pp}$.

Sen, B. \& Sonmez, F. 2006. A Study on the Algae in Fish Pond and Their Seasonal Variations. International J. of Science \& Technology, 1(1): 25-33.
Shirota, A. 1966. Plankton of South Vietnam: Freshwater and Marine Plankton. Over Tech. Coop. Agen. Japan, 484 pp.

Sonnenholzner, S. \& Boyd, C.E. 2000. Chemical and Physical Properties of Shrimp Pond Bottom Soil in Ecuador. J. of The World Aquaculture Society, 31(3): 358-375.

Soil Survey Staff. 1990. Key to Soil Taxonomy, $4^{\text {th }}$ edition. Soil Management Support Service, Technical Monograph Number 19. Virginia Polytechnical Institute and State University, Blacksburg, Virginia, USA, 541 pp.

Watyandari. 2007. Strategi Pemasaran Benih Ikan BBI Cangkringan. Thesis, Prog. Studi Magister Manajemen UGM, 168 pp.

Wetzel. R.G. \& Likens, G.E. 1991 . Limnological Analyses. Second Edition. Springer-Verlag New York, Inc., 391 pp.

Wurts, W.A. \& Durborow, R.M. 1992. Interaction of $\mathrm{pH}$, Carbon Dioxide Alkalinity and Hardness in Fish Ponds. SRAC Publication No. 464, 4 pp.

Yilmaz, K., Celik, I., Kapur, S., \& Ryan, J. 2005. Clay Mineral, $\mathrm{Ca} / \mathrm{Mg}$ Ratio and Fe-Al-Oxides in Relation to Structural Stability, Hydraulic Conductivity and Soil Erosion in Southeastern Turkey. Turk J. Agric For., p. 29-37. 